\title{
Relation between Democratic Leadership and Organizational Cynicism
}

\author{
Ali Riza Terzi ${ }^{1} \&$ Ramazan Derin ${ }^{2}$ \\ ${ }^{1}$ Department of Educational Sciences, Necatibey Faculty of Education, Balıkesir University, Balıkesir, Turkey \\ ${ }^{2}$ Department of Educational Sciences, Graduate School of Social Sciences, Balıkesir University, Postgraduate \\ Student, Balıkesir, Turkey \\ Correspondence: Ali Rıza Terzi, Department of Educational Sciences, Necatibey Faculty of Education, Balıkesir \\ University, Balıkesir, 10100, Turkey. Tel: 90-266-241-2762. E-mail: terzioglu53@hotmail.com
}

Received: April 20, 2016

Accepted: May 20, $2016 \quad$ Online Published: June 16, 2016

doi:10.5539/jel.v5n3p193

URL: http://dx.doi.org/10.5539/jel.v5n3p193

\begin{abstract}
This study intends to analyze the relation between school principals' leadership styles and teachers' perception of organizational cynicism. The study group consists of 268 participants teaching at high schools in the Balıkesir district of Turkey during 2014-2015 academic year. In the study, which used relational survey model, data was collected through Democratic Leadership Scale and Organizational Cynicism Scale and analyzed by mean scores, independent t-test, one-way analysis of variance (ANOVA), and simple linear regression. The results revealed that democratic leadership is a significant predictor of organizational cynicism, and it is negatively connected with organizational cynicism. In addition, it was found that there were significant differences between seniority and gender groups as regards democratic leadership, between seniority groups as regards all dimensions of organizational cynicism, and between gender as regards affective cynicism. All the results of the study showed that the democratic leadership style displayed by school principals influences the organizational cynicism perceived by teachers.
\end{abstract}

Keywords: democratic leadership, high school teachers, leadership skills, management, organizational cynicism, school principals

\section{Introduction}

Leadership is a topic of special interest in the management literature. This can be attributed to the lure of leaders "power to have their followers behave in a particular way on voluntary basis. Discussions on leadership have exceeded its scope, breeding the generally acknowledged approach that "leadership is an impact approved by the group" (Yukl, 1989; Bohn \& Grafton, 2002).

There is a general consensus in the related literature that leadership affects nearly all organizational and individual variables (organizational culture, organizational commitment, organizational citizenship behavior, organizational trust, organizational support, job satisfaction, motivation, etc.) (Y1lmaz, 2004; Korkmaz, 2007; Çakınberk \& Demirel, 2010; Acar, 2013; Doğan \& Uğurlu, 2014; Uluköy, Kılıç, \& Bozkaya, 2014). Organizational cynicism is another variable, whose relation with leadership is a focus of research (Lee \& Moon, 2010; Nguyen, 2013; Gkorezis, Petridou, \& Krouklidou, 2015). Organizational cynicism is defined as the negative attitude an employee has toward the organization where he or she works (Yalçınkaya, 2014). Dean, Brandes and Dharwadkar (1998) added to the definition of cynicism the employee's belief that the organization lacks coherence and integrity.

Analysis of the effect of leadership on related variables could well be conducted in educational organizations. This study investigates the relation between democratic leadership and organizational cynicism by using a sample of high school teachers. The present study has theoretical significance in that it will shed light on the effect of school principals' democratic leadership on the existence of cynicism at schools, which are educational organizations. It has practical significance in that the findings of the study will help school administrators understand the importance of school's informal side. 


\subsection{Democratic Leadership}

The term democratic leadership was conceptualized in 1960's by White and Lippitt. In this leadership style, leader-encouraged group involvement in the decision making process was emphasized (Choi, 2007). Gastil (1994) conceptually differentiated between democratic leadership and being authoritarian, defining it as delegation of responsibility among group members, empowerment of group members, and assistance provided by group members through the decision making process functions. Democratic leadership favors the leader's sharing of managerial power with the group members (Eren, 2001). The most remarkable characteristic of this leadership style is that the leader consults the members' opinions when setting goals, plans, and policies (Başaran, 1992; Tengilimoğlu, 2005). As democratic leadership is an ethical entity, it ensures individuals' right to participate, respect for all members, and fulfillment of expectations, as a result of which democracy spreads through structures and network of educational institutions (Woods, 2004).

It is stated in the literature that the production performance and employee satisfaction are in the long run higher in organizations governed by democratic leadership than in those governed by other leadership styles (Robbins \& Coulter, 2012; Lunenburg \& Ornstein, 2013). It is also indicated that democratic leadership is a complete leadership with various elements, and in order for it to achieve highest quality, these elements (participation, equality, freedom, consensus, communication, emotional intelligence -human relations-, cooperation; use of authority, democratic culture) should be in perfect coordination (Yörük \& Kocabaş, 2001).

As Ocak (2014) asserts, democratic leadership benefits for individuals and organizations in several ways. It boosts motivation, allows for using subordinates' knowledge and experience in the decision making process, creates loyalty to the team's goals, and ensures mutual communication, thus eliminating potential communication problems. Therefore, democratic leadership seems to be an effective leadership approach.

Leadership is accepted as the major cause of success or failure (Kouzes \& Posner, 2009; Hoy \& Miskel, 2010), and projections of leadership especially in the areas of education and public administration overwhelmingly show the necessity of being more democratic.

Studies focusing on democratic leadership in educational institutions (Yörük \& Kocabaş, 2001; Harris \& Chapman, 2002; Gezici, 2007; Bozdoğan \& Sağnak, 2011; Bhatti, Maitlo, Shaikh, Hashmi, \& Shaikh, 2012; Adeyemi \& Adu, 2013; Aydın \& Sarıer, 2013; Mbera, 2015) and in enterprises (Woods, 2004; Şafaklı, 2005; Choi, 2007; Kızlttay, 2010; Yörük \& Dündar, 2011) demonstrated the importance of democratic leadership for organizations, so obviously it is a researchable subject.

\subsection{Organizational Cynicism}

Research related to organizational cynicism dates back to early 90's. The concept of organizational cynicism emerged following Kanter and Mirvis's study on American employees (James, 2005). Numerous definitions of organizational cynicism exist in the literature. Researchers point out some foundational difficulties concerning the conceptualization of organizational cynicism, which stems from the complexity of the process (Naus, 2007; Tokgöz \& Yilmaz, 2008).

Andersson and Bateman (1997) define organizational cynicism as employees' negative attitude and judgement toward their organization, its structure, and processes. Dean et al. (1998), on the other hand, define organizational cynicism as the negative feelings an individual has developed for his or her workplace. They included three dimensions in their definition: the belief that the organization lacks integrity and honesty, the negative feelings one has about the organization, and one's tendency to criticize the institution and act with hostility. Abraham's (2000) definition of organizational cynicism involves one's "negative emotional reaction to", "tendency to disparage", and "harsh criticism of" the workplace.

Organizational cynicism is analyzed in three aspects (cognitive, affective, and behavioral) in the related literature. The cognitive dimension entails the belief that the organization lacks integrity. Affective dimension entails such negative emotions as disrespect, anger, pain, and embarrassment. It is also defined as experience gained through intuition, as well as thought, or through feelings, as well as cognition. The behavioral dimension, on the other hand, generally involves despising and negative behaviors (harsh criticism of the organization, use of teasing and sarcastic humor, etc.) (Dean et al., 1998; Abraham, 2000).

Studies on organizational cynicism have revealed the characteristics and significance of cynicism in different ways. Anderson and Bateman (1997) claimed that cynical people have less tendency to take unethical requests into consideration. On the other hand, in the behavior dimension of organizational cynicism, cynical employees cite various criticisms toward their organizations, which can be a motive for the organization's development and improvement provided that they are expressed properly (Arslan, 2012). 
Numerous studies exist in the literature focusing on the reasons for organizational cynicism. Cole, Bruch and Vogel (2006), for example, determined that leadership skills, organizational support, administrative competence, trust for the administration, and work environment are the predictors of cynicism. Organizational cynicism emerges when employees believe that the organization is deprived of integrity, which is usually a result of their basic expectations like justice, ethics, and honesty not being fulfilled (Karacaoğlu \& İnce, 2013). Other studies provided evidence that personal factors that bring about organizational cynicism are age, gender, marital status, seniority, income, educational background, professional status/tittle, anxiety, distrust, disappointment, and humiliation. Organizational factors leading to cynicism, however, are organizational justice, psychological violation of the contract, role conflict, hierarchy, inequality, ineffective leadership, long shifts, lay-offs, institutional policies, unethical behaviors, organizational performance, and supervisor-employee interaction (Davis \& Gardner, 2004; Delken, 2004; Kalağan, 2009; Bashir, 2011; Kılıç, 2011; Korkmaz, 2011; Polatcan, 2012; Akman, 2013; Gövez, 2013; Gündüz, 2014; Sancak, 2014; Ergen, 2015).

The results of studies focusing on organizational cynicism have demonstrated that cynicism brings about many adverse effects on individuals and organizations. Abraham (2000) asserted that organizational cynicism hinders job satisfaction, organizational commitment, and organizational citizenship, leading to frustration at work and alienation. It was also stated in the literature that organizational cynicism causes some adverse effects such as distrust, burn-out, alienation, and psychological consequences associated with neural-emotional disorder, depression, fatigue, emotional burnout, frustration, anger, resentment, aggression, tension, and anxiety (Akman, 2013; Y1ldız, Akgün, \& Y1ldı, 2013).

The related literature has also revealed that (James, 2005; Escamilla-Quintal, Rodríguez-Molina, Peiró, \& Marco, 2008; Kalağan \& Aksu, 2010; Özgan, Külekçi, \& Özkan, 2012; Yetim \& Ceylan, 2011; Aslan \& Yılmaz, 2013; Yıldız et al., 2013; Karadağ, Kılı̧̧oğlu, \& Yılmaz, 2014; Ching, 2015) organizational cynicism gives harm to the organization, which stresses the importance of the problem and the need to probe it.

\subsection{Democratic Leadership and Organizational Cynicism Relation}

Although many studies in the related literature have focused on the relation between different types of leadership and organizational cynicism, few, if any, studies exist on the relation between democratic leadership style and organizational cynicism. The studies on the relation between leadership styles and organizational cynicism show that leadership styles and organizational cynicism are negatively connected; as levels of sincere leadership, ethical leadership, transformational leadership, interactive leadership, spiritual leadership and leader-member interaction increase, organizational cynicism decreases (Davis \& Gardner, 2004; Bommer, Rich, \& Rubin, 2005; Wu, Neubert, \& Yi, 2007; Gövez, 2013; Akan, Bektaş, \& Yıldırım, 2014; Gündüz, 2014; Sancak, 2014).

Studies have recently been conducted in Turkey analyzing the relation between democratic leadership styles and organizational cynicism in educational organizations (Polatcan, 2012; Mete, 2013; Doğan \& Uğurlu, 2014), which also supported the findings that various leadership styles and organizational cynicism are negatively connected. This also shows that the relation between democratic leadership style and organizational cynicism is a potential subject of research in educational organizations.

\subsection{Purpose of the Study}

The present study aims to explore the relation between democratic leadership and organizational cynicism at school organizations within the context of Turkey. To this end, it seeks answers to the following research questions:

1) What is the extent to which teachers perceive democratic leadership and organizational cynicism at the high schools where they work?

2) How do teachers' perception of democratic leadership and organizational cynicism differ according to their;

a) gender,

b) seniority?

3) Is democratic leadership a predictor of organizational cynicism? 


\section{Methodology}

Descriptive survey method was used in the study. The data collected through "Democratic Leadership Scale" and "Organizational Cynicism Scale" was analyzed using quantitative methods.

\subsection{Study Group}

The study group consists of teachers working at 16 Ministry of Education high-schools in Altieylül and Karesi center provinces of Balıkesir in Turkey in 2014-2015 academic year. According to the records of the District Directory of Ministry of Education, in this academic year, 742 teachers (397 male, 345 female) were working. All the teachers in the study group were included on the study. The study was conducted based on data obtained from 268 participants who returned the data collection tools. Of the participants, $125(46.6 \%)$ are female, and $143(53.4 \%)$ are male. The sample used in the study represents the greater population by 36.1 percent.

\subsection{Data Collection Instruments}

\subsubsection{Democratic Leadership Scale}

Democratic leadership scale used in the study was developed by Terzi (2015). The scale consists of 8 items, all of which are 5-point Likert scale items with response options "Never" (1), Seldom" (2), "Sometimes" (3), "Often" (4), "Always" (5).

The reliability and validity of the scale was measured again. The Explanatory Factor Analysis (EFA) conducted revealed that KMO value of the democratic leadership scale is .90, and Barlett Sphericity value is $\chi^{2}=1003.64$. Its significance value exceeded .00 . Total variance explained by democratic leadership scale is 56 percent. The scale is a single-dimensional scale. Cronbach's Alpha was used to measure the reliability of the scale. Alpha value was found to be $\mathrm{a}=89$. The total item correlations of the scale ranged between .57 and .81 .

\subsubsection{Organizational Cynicism Scale}

Organizational cynicism scale was developed by Brandes, Dharwadkar and Dean (1999). Kalağan (2009) adapted the tool to Turkish. It consists of items including affirmative statements and three dimensions, namely cognitive, affective, and behavioral dimensions. Organizational cynicism scale has five items in the cognitive dimension, four items in the affective dimension, and four items in the behavioral dimension. It is a five-point Likert type scale with the following response options: "Strongly disagree" (1), "Disagree" (2), "Partially agree" (3), "Agree" (4), "Strongly agree" (5). In the adaptation of the scale, factor loads determined by Kalagan (2009) ranged between 0.76 and 0.82 in cognitive dimension, 0.74 and 0.88 in affective domain, and 0.67 and 0.89 in behavioral domain. The total variance explained by the scale is 78.674 percent. Cronbach Alpha internal consistency coefficient of the scale is 0.93 overall. It is 0.91 in cognitive domain, 0.95 in affective domain, 0.87 in behavioral domain. Total item correlation was found to be between .54 and .89 . Validity and reliability analyses were reapplied to the organizational cynicism scale. Explanatory Factor Analysis produced the KMO value of 0.90 and Bartlett Sphericity value of $\chi^{2}=2227.049(\mathrm{p}<0,00)$. Cognitive Cynicism parameter of the scale explained 29 percent of the variance, affective cynicism parameter 25 percent of the variance, and behavioral parameter 16 percent of the variance. The overall variance explained by the scale is 71 percent. Cronbach Alpha calculation was made to reapply reliability analysis of the scale. This value was found to be a $=.86$ in the cognitive dimension, $\mathrm{a}=.94$ in the affective dimension, and .77 in behavioral dimension. The overall Cronbach Alpha coefficient value of the scale is .90. The total item correlation of the scale varies between .57 and .75 .

\subsection{Data Analysis}

In data analysis, arithmetic mean was used to determine the participants' level of perception for the democratic leadership behaviors of the principals at their schools and organizational cynicism; t-test was used for the difference according to gender; one-way variance analysis was used for the difference according to the seniority variable; Scheffe test was used to find among which groups variance exists and simple linear regression analysis was used to compute the predictability of organizational cynicism by democratic leadership. 


\section{Results}

Table 1 presents the participants' perception of the democratic leadership behaviors of the principals at their schools and organizational cynicism.

Table 1. Teachers' perception of democratic leadership and organizational cynicism

\begin{tabular}{lllll}
\hline Scale & Dimensions & $\mathrm{N}$ & $\bar{X}$ & $\mathrm{sd}$ \\
\hline Democratic leadership & & 268 & 3.73 & .78 \\
& Cognitive cynicism & 268 & 2.46 & .78 \\
Organizational cynicism & Affective cynicism & 268 & 1.77 & .76 \\
& Behavioral cynicism & 268 & 2.47 & .86 \\
\hline
\end{tabular}

As can be seen in Table 1 , teachers believe that school principals "often" $(\bar{\chi}=3.73$; sd $=.78)$ display democratic leadership behaviors. As regards organizational cynicism, teachers stated that they never experienced affective cynicism $(\bar{\chi}=1.77$; sd $=.76)$, while they pointed to the presence of cognitive and behavioral cynicism at their schools $(\bar{\chi}=2.46$; sd $=.78 ; \bar{\chi}=2.47$; sd $=.86)$. Table 2 presents the difference between democratic leadership and organizational cynicism according to gender.

Table 2. T-test for democratic leadership and cynicism according to gender

\begin{tabular}{lllllllc}
\hline Sub-dimensions & Gender & $\mathrm{N}$ & $\bar{X}$ & $\mathrm{sd}$ & $\mathrm{df}$ & $\mathrm{t}$ & $\mathrm{p}$ \\
\hline \multirow{2}{*}{ Democratic leadership } & Female & 125 & 3.59 & .76 & \multirow{2}{*}{266} & -2.734 & $.007^{* *}$ \\
& Male & 143 & 3.85 & .78 & & & \\
Cognitive Cynicism & Female & 125 & 2.50 & .78 & \multirow{2}{*}{.56} & .795 & .42 \\
& Male & 143 & 2.43 & .78 & & & \\
Affective Cynicism & Female & 125 & 1.88 & .79 & & & \\
& Male & 143 & 1.68 & .79 & 266 & 2.162 & $.032^{*}$ \\
Behavioral Cynicism & Female & 125 & 2.47 & .87 & & & \\
& Male & 143 & 2.47 & .84 & 266 & .039 & .96 \\
\hline
\end{tabular}

$* \mathrm{p}<.05, * * \mathrm{p}<.01$.

As can be seen in Table 2, teachers' perceptions varied significantly according to gender as regards democratic leadership ( $\mathrm{t}=-2.734 ; \mathrm{p}=.007 ; \mathrm{p}<.01)$; male teachers' belief that schools principals are democratic is greater than that of female teachers. Similarly, in affective level, female teachers tend to be more cynical than male teachers $(\mathrm{t}=-2.162 ; \mathrm{p}=.032 ; \mathrm{p}<.05)$. Table 3 presents data on whether democratic leadership and organizational cynicism differ according to teachers' seniority. 
Table 3. Anova for democratic leadership and cynicism according to seniority

\begin{tabular}{llccccccc}
\hline Variables & Seniority & $\mathrm{N}$ & $\bar{X}$ & $\mathrm{sd}$ & $\mathrm{F}$ & $\mathrm{df}$ & $\mathrm{p}$ & Scheffé \\
\hline Democratic leadership & (a) $1-5$ years & 120 & 3.70 & .75 & 3.450 & 265 & $.033^{*}$ & b-c \\
& (b) 6-10 years & 78 & 3.60 & .86 & & & & \\
& (c) $11+$ & 70 & 3.93 & .71 & & & & \\
Cognitive Cynicism & (a) $1-5$ years & 120 & 2.50 & .73 & 6.847 & 265 & $.001^{* *}$ & a-c \\
& (b) 6-10 years & 78 & 2.65 & .85 & & & & b-c \\
& (c) $11+$ & 70 & 2.19 & .73 & & & & \\
Affective Cynicism & (a) $1-5$ years & 120 & 1.85 & .74 & 4.184 & 265 & $.016^{*}$ & a-c \\
& (b) $6-10$ years & 78 & 1.84 & .79 & & & & b-c \\
Behavioral Cynicism & (c) $11+$ & 70 & 1.55 & .71 & & & & \\
& (a) $1-5$ years & 120 & 2.55 & .81 & 4.720 & 265 & $.010^{* *}$ & a-c \\
& (b) 6-10 years & 78 & 2.59 & .85 & & & & b-c \\
& (c) $11+$ & 70 & 2.20 & .91 & & & & \\
\hline
\end{tabular}

$* \mathrm{p}<.05 * \mathrm{p}<.01$

As can be seen in Table 3, secondary education teachers' perception of democratic leadership differs significantly according to their school seniority $(\mathrm{p}=.033 ; \mathrm{p}<.05)$. Scheffe test results show that democratic leadership scores of teachers with $6-10$ years of seniority $(\bar{\chi}=3,60 ; \mathrm{sd}=.86)$ and those with 11 and more years of seniority $(\bar{\chi}=3.93 ; \mathrm{sd}=.71)$ differ significantly. Here, it is also seen that organizational cynicism differs by seniority (Cognitive Cynicism: $\mathrm{p}=.001 ; \mathrm{p}<.01$; Affective Cynicism $\mathrm{p}=.016 ; \mathrm{p}<.05$; behavioral cynicism: $\mathrm{p}$ $=.010 ; \mathrm{p}<.05)$. As regards cognitive cynicism, this difference exists between teachers with $1-5$ years $(\bar{\chi}=2.50$; $\mathrm{sd}=.73)$ of school seniority and those with 11 and more years of school seniority $(\bar{\chi}=2.19$; sd $=.73)$. Similarly, there is a difference between teachers with $6-10$ years $(\bar{\chi}=2.65 ; \mathrm{sd}=.85)$ of seniority and those with 11 and more years of seniority $(\bar{\chi}=2.65 ; \mathrm{sd}=.73)$. As regards affective and behavioral cynicism, the difference is between the same groups of teachers. Table 4 presents the results of regression analysis concerning the predictability of organizational cynicism by democratic leadership.

Table 4. Regression analysis on the prediction of democratic leadership and cynicism

\begin{tabular}{llllllll}
\hline Variables & $\mathrm{B}$ & $\mathrm{R}$ & $\mathrm{R}^{2}$ & $\beta$ & $\mathrm{t}$ & $\mathrm{F}$ & $\mathrm{p}$ \\
\hline Constant & 3.795 & & & & 22.316 & 87.455 & $000^{* *}$ \\
Democratic leadership & -.417 & .50 & .25 & -.50 & -9.352 & & $000^{* *}$ \\
& & & & & & & \\
\hline$* * \mathrm{p}<.01$. & & & & & &
\end{tabular}

As can be seen in Table 4, democratic leadership and organizational cynicism are significantly and negatively connected at moderate level. In addition, democratic leadership explains 25 percent of the total variance in organizational cynicism $\left(\mathrm{R}=.50, \mathrm{R}^{2}=.25, \mathrm{p}=.00\right)$. That is, democratic leadership explains 25 percent of the variance that occurs in organizational cynicism significantly. The total effect of democratic leadership on cynicism is $\beta=-.50$. Thus, it can be concluded that democratic leadership is a significant predictor of organizational cynicism.

\section{Discussion}

This study investigated the relation between school principals' democratic leadership styles and the perceived organizational cynicism based on the opinions expressed by high school teachers. It was found that teachers identify their school principals as administrators "often" with democratic leadership style. A similar result was found by Terzi and Çelik (2016), who aimed to determine the relation between school principals' leadership 
styles and perceived organizational support. They found that, according to primary school and high school teachers, school administrators "often" display democratic leadership behaviors. There are studies conducted in Turkey and abroad that confirm this result of the research (Özday1, 1998; Terzi \& Kurt, 2005; Bozdoğan \& Sağnak, 2011; Adeyemi \& Adu, 2013). They show that school principals generally display democratic leadership. Teachers strongly disagreed that there was Affective Cynicism and disagreed that there was cognitive and behavioral Cynicism. The fact that teachers perceive low levels of organizational cynicism, which adversely affects organizational performance and success, despite many problems and hardships encountered at schools is a promising result about schools' future success and quality of education. Karadağ et al. (2014) conducted a study at primary schools, and they similarly concluded that organizational cynicism perceived by teachers is low. The cynicism perceived in their study was as follows in decreasing mean average: Behavioral Cynicism, Cognitive Cynicism, and Affective Cynicism. Yıldız et al. (2013) and Atmaca (2014) focused on primary, secondary, and high schools to find that, slightly connected as they are, teachers' organizational cynicism correlates the most with behavioral dimension, and the least with affective dimension.

As to democratic leadership, gender groups differed significantly. In fact, male teachers had greater belief than female teachers that school principals display democratic leadership style. The related literature shows that there is no significant relation between democratic leadership and gender (Gezici, 2007; İbicioğlu, Özmen, \& Taş, 2009; Kızıltay, 2010; Ocak, 2014; Terzi \& Çelik, 2016). Indeed, there are few, if any, studies that are in concordance with this finding of the study. Terzi and Kurt (2005), who investigated the effect of primary school teachers' administrative behaviors on teachers' organizational commitment, observed that male teachers have a greater tendency than female teachers to believe that school administrators are authoritarian, and indifferent. Pertaining to transactional leadership, however, Beşiroğlu (2003) found that gender groups differed significantly in their belief that school principals are transactional leaders. Indeed, it was the female teachers that had greater belief in the transactional leadership skills of the school principals. The results of these studies are in agreement with those of the present study.

The findings of the study show that female teachers are significantly more cynical than male teachers in affective dimension. In other words, female teachers reported that they experience affective cynicism more than male teachers do. Gövez (2013) carried out a study at a private company, finding out a significant difference between employees according to gender; the Affective Cynicism mean-scores of female employees are higher than those of male employees. This result is in concordance with the findings of the present study. There are studies conducted out of Turkey that confirm this finding of the study (Lobnikar \& Pagon, 2004; Töyry et al., 2004). Although Polatcan (2012) and Gündüz (2014) also observed that affective cynicism varies significantly according to gender, they found out that, unlike the findings of the present study, male teachers are significantly more cynical.

As regards perception of leadership, the findings of the study provide evidence that there is a significant difference between teachers according to their seniority at the school; in fact, this difference exists between teachers with 6-10 years of seniority and those with 11 and above years of seniority. Teachers with 11 years and above seniority find their school principals more democratic than those with 6-10 years of seniority do. There are other studies whose results are in agreement with this finding. Terzi and Çelik (2016) found that, as to indifferent leadership style, there is a significant difference between seniority groups of teachers; teachers with 11 and more years of seniority have a greater tendency, than teachers with 1-10 years of seniority, to perceive that schools principals are indifferent leaders. Similarly, Avc1 (2015) concluded that, in terms of transformational and transactional leadership styles, teachers' perceptions differed significantly according to the total duration of work at a certain school. As a matter of fact, teachers with 0-1 year, 2-3 years, and 11 and more years of experience tend to believe that the school principals display transformational leadership style, and teachers with $0-1$ year, 2-3 years, and 6-7 years of experience tend to believe that school principals display transactional leadership behaviors. By contrast, Gezici (2007), Tura (2012) and Özkan (2014) found no significant difference between seniority groups concerning leadership styles.

As regards organizational cynicism, there is a significant difference between teachers according to seniority. This difference exists in all dimensions of organizational cynicism, and between the following seniority groups: 1-5 years and 11 years and above; 6-10 years and 11 years and above. Indeed, teachers with 1-5 years and 6-10 years of seniority have greater cognitive, affective, and behavioral cynicism toward their organization than teachers with 11 years and above seniority. Gövez (2013) determined that employees' duration of work at a school affect all subdimensions of organizational cynicism significantly; teachers with 1-5 years of school seniority were found to have higher cognitive, affective, and behavioral cynicism scores than those with 6 years 
of seniority. Other studies exist in the related literature providing evidence that there is a significant connection between organizational cynicism and school seniority (Helvacı \& Çetin, 2012).

The present research concluded that democratic leadership explains $25 \%$ of the variance in organizational cynicism, and thus democratic leadership is a significant predictor of organizational cynicism. It is also noteworthy that democratic leadership and organizational cynicism were found to be significantly and negatively connected at moderate level, which can be interpreted as "the more democratic leadership behaviors school principals display, the less cynical teachers are toward their organizations". Other studies whose findings are in concordance with this finding (Coşar, 2011; Gövez, 2013) yielded that transformational, interactive, and authentic leadership styles are significant predictors of organizational cynicism. Thus, it can be concluded that the leadership styles displayed by school principals influence organizational cynicism.

\section{Conclusion}

The results of the study revealed that the high school teachers perceive high levels of democratic leadership quality with the school principals. In addition, teachers' level of organizational cynicism is low. It was found that female teachers have mostly affective cynicism. Democratic leadership and the length of teaching at a particular school were found to be related with the cynicism they experience. Teachers who are more senior members of an educational institution tend to believe that school principals are democratic, and they view the procedures at their school with less cynicism when compared with more junior teachers. The major finding of the study is that democratic leadership is a significant predictor of organizational cynicism.

Based on the results of the study, it could be suggested that school principals adopt the democratic leadership style, which plays an important role in reducing organizational cynicism and increasing organizational performance and success. In addition, possession of democratic leadership qualities might be a criterion in appointment of school principals.

The study was conducted in just one city of Turkey. Further studies should be conducted in different levels and regions of education with greater sample size. What is more, this study focused solely on the relation between democratic leadership style and organizational cynicism. Further studies should be conducted analyzing democratic leadership style in relation with organizational commitment, job satisfaction, organizational trust, and justice.

\section{References}

Abraham, R. (2000). Organizational cynicism: Bases and consequences. Genetic, Social, and General Psychology Monographs, 126(3), 269-292.

Acar, A. Z. (2013). Farklı örgüt kültürü tipleri ve liderlik tarzları ile örgütsel bağlılık arasındaki ilişki: Lojistik işletmelerinde bir araştırma. İ̧̧letme Araştırmaları Dergisi, 5(2), 5-31.

Adeyemi, T. O., \& Adu, E. T. (2013). Head teachers' leadership styles' and teachers job satisfaction in primary schools in Ekiti State, Nigeria. International Journal of Academic Research in Economics and Management Sciences, 2(2), 69-79.

Akan, D., Bektaş, F., \& Yıldırım, İ. (2014). Sınıf öğretmeni algılarına göre etik liderlik ve örgütsel sinizm

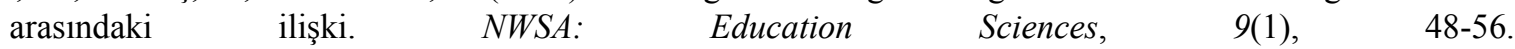
http://dx.doi.org/10.12739/NWSA.2014.9.1.1C0605

Akman, G. (2013). Sağllk çalışanlarının örgütsel ve genel sinizm düzeylerinin karşılaştırılması (Yayınlanmamış yüksek lisans tezi). İstanbul Üniversitesi, İstanbul, Türkiye.

Andersson, L. M., \& Bateman, T. S. (1997). Cynicism in the workplace: Some causes and effects. Journal of Organizational Behavior, 18(5), 449-469. http://dx.doi.org/10.1002/(SICI)1099-1379(199709)18:5<449::AID-JOB808>3.0.CO;2-O

Arslan, E. T. (2012). Süleyman Demirel Üniversitesi İktisadi ve İdari Bilimler Fakültesi akademik personelinin genel ve örgütsel sinizm düzeyi. Doğuş Üniversitesi Dergisi, 13(1), 12-27.

Aslan, H., \& Y1lmaz, E. (2013). The Study of teachers' general cynicism inclinations in terms of life satisfaction and other variables. Creative Education, 4(9), 588-591. http://dx.doi.org/10.4236/ce.2013.49084

Atmaca, T. (2014). Okul yöneticilerinin kullandıkları güç türleri ile öğretmenlerin yaşadıkları yıldırma, örgütsel bağglllı ve örgütsel sinizm arasındaki ilişki (Yayınlanmamış yüksek lisans tezi). Gazi Üniversitesi, Ankara, Türkiye. 
Avcı, A. (2015). Öğretmen algılarına göre okul müdürlerinin liderlik stilleri. Hasan Âli Yücel Eğitim Fakültesi Dergisi, 12(2), 161-189.

Bashir, S. (2011). Organizational cynicism development and testing of an integrated model a study of public sector employees in Pakistan (Unpublished doctoral dissertation). Mohammad Ali Jinnah University, Islamabad, Pakistan.

Başaran, İ. E. (1992). Yönetimde İnsan İlişkileri. Ankara: Kadığlu Matbaası.

Beşiroğlu, A. (2013). Ortaöğretim kurumları yöneticilerinin liderlik stillerinin örgütsel bağlllıkla ilişkisi (Yayınlanmamış yüksek lisans tezi). Marmara Üniversitesi, İstanbul, Türkiye.

Bhatti, N., Maitlo, G. M., Shaikh, N., Hashmi, M. A., \& Shaikh, F. M. (2012). The impact of autocratic and democratic leadership style on job satisfaction. International Business Research, 5(2), 192-201. http://dx.doi.org/10.5539/ibr.v5n2p192

Bohn, J. G., \& Grafton, D. (2002). The relationship of perceived leadership behaviors to organizational efficacy. Journal of Leadership and Organizational Studies, 9(2), 65-80. http://dx.doi.org/10.1177/107179190200900206

Bommer, W. H., Rich, G., \& Rubin, R. S. (2005). Changing attitudes about change: Longitudinal effects of transformational leader behavior on employee cynicism about organizational change. Journal of Organizational Behavior, 26(7), 733-753. http://dx.doi.org/10.1002/job.342

Bozdoğan, K., \& Sağnak, M. (2011). İlköğretim okulu müdürlerinin liderlik davranışları ile öğrenme iklimi arasındaki ilişki. Abant İzzet Baysal Üniversitesi Eğitim Fakültesi Dergisi, 11(1), 137-145.

Brandes, P., Dharwadkar, R., \& Dean, J. W. (1999). Does Organizational Cynicism Matter? Employee And Supervisor Perspectives On Work Outcomes. Eastern Academy of Management Proceedings, 150-153.

Choi, S. (2007). Democratic leadership: The lessons of exemplary models for democratic governance. International Journal of Leadership Studies, 2(3), 243-262.

Cole, M. S., Bruch, H., \& Vogel, B. (2006). Emotion as mediators of the relations between perceived supervisor support and psychological hardiness on employee cynicism. Journal of Organizational Behavior, 27(4), 463-484. http://dx.doi.org/10.1002/job.381

Coşar, S. (2011). Otantik liderlik kavramı ve ardılları üzerine bir araştırma (Yayınlanmamış yüksek lisans tezi). Kara Harp Okulu, Ankara, Türkiye.

Çakınberk, A., \& Demirel, E. T. (2010). Örgütsel bağlılığın belirleyicisi olarak liderlik: Sağlık çalışanları örneği. Selçuk Üniversitesi Sosyal Bilimler Enstitüsü Dergisi, 24, 103-119.

Davis, W. D., \& Gardner, W. L. (2004). Perceptions of politics and organizational cynicism: An attributional and leader-member exchange perspective. The Leadership Quarterly, 15(4), 439-465. http://dx.doi.org/10.1016/j.leaqua.2004.05.002

Dean, J. W., Brandes, P., \& Dharwadkar, R. (1998). Organizational cynicism. The Academy of Management Review, 23(2), 341-352.

Delken, M. (2004). Organizational cynicism: A study among call centers (Unpublished master's thesis). University of Maastricht, Maastricht, Netherlands.

Doğan, S., \& Uğurlu, T. C. (2014). Okul yöneticilerinin etik liderlik davranışları ile öğretmenlerin örgütsel sinizm algıları arasındaki ilişki. Gazi Üniversitesi Gazi Eğitim Fakültesi Dergisi, 34(3), 489-516.

Eren, E. (2001). Örgütsel davranışv ve yönetim psikolojisi (7. bask1). İstanbul: Beta Basım Yayın.

Ergen, S. (2015). Öğretmenlerin örgütsel sinizm düzeyleri ile örgütsel bă̆llllkları arasındaki ilişki (Yayınlanmamış yüksek lisans tezi). Gazi Üniversitesi, Ankara, Türkiye.

Escamilla-Quintal, M., Rodríguez-Molina, I., Peiró, J. M., \& Marco, I. T. (2008). Cynicism: A differential coping strategy as a function of gender. Psicothema, 20(4), 596-602.

Gastil, J. (2014). A definition and illustration of democratic leadership. Human Relations, 47(8), 953-975. http://dx.doi.org/10.1177/001872679404700805

Gezici, A. (2007). Yöneticilerin liderlik stillerinin çalışanların iş tatmini üzerindeki etkileri: Ozel eğitim kurumlarında ögretimsel liderlik ve bir uygulama (Yayınlanmamış yüksek lisans tezi). Dumlupınar Üniversitesi, Kütahya, Türkiye. 
Gkorezis, P., Petridou, E., \& Krouklidou, T. (2015). The detrimental effect of machiavellian leadership on employees' emotional exhaustion: Organizational cynicism as a mediator. Europe's Journal of Psychology, 11(4), 619-631. http://dx.doi.org/10.5964/ejop.v11i4.988

Gövez, E. (2013). Örgütsel sinizm ve dönüştürücü/etkileşimci liderlik arasındaki ilişki (Yayınlanmamış yüksek lisans tezi). Atatürk Üniversitesi, Erzurum, Türkiye.

Gündüz, Ş. (2014). Ruhsal liderlik ile örgütsel sinizm arasındaki ilişsi: Duygusal zekânın aracı etkisi (Yayınlanmamış doktora tezi). Marmara Üniversitesi, İstanbul, Türkiye.

Harris, A., \& Chapman, C. (2002). Democratic leadership for school improvement in challenging contexts. International Electronic Journal for Leadership in Learning, 6(9).

Helvacı, M. A., \& Çetin, A. (2012). İlköğretim okullarında görev yapan öğretmenlerin örgütsel sinizm düzeylerinin belirlenmesi (Uşak ili örneği). International Periodical For The Languages, Literature and History of Turkish or Turkic, 7(3), 1475-1497.

Hoy, W. K., \& Miskel, C. G. (2005/2012). Eğitim Yönetimi: Teori, Araştırma ve Uygulama (Çev. S. Turan). Ankara: Nobel Yayın Dă̆ı̆ım.

İbicioğlu, H., Özmen, H. İ., \& Taş, S. (2009). Liderlik davranışı ve toplumsal norm ilişsisi: Ampirik bir çalışma. Süleyman Demirel Üniversitesi İktisadi ve İdari Bilimler Fakültesi Dergisi, 14(2), 1-23.

James, M. S. L. (2005). Antecedents and consequences of cynicism in organizations: An examination of the potential positive and negative effects on school systems (Unpublished doctoral dissertation). The Florida State University College Of Business, Florida, USA.

Kalağan, G. (2009). Araştırma görevlilerinin örgütsel destek algıları ile örgütsel sinizm tutumları arasındaki ilişki (Yayınlanmamış yüksek lisans tezi). Akdeniz Üniversitesi, Antalya, Türkiye.

Kalağan, G., \& Aksu, M. B. (2010). Organizational cynicism of the research assistants: A case of Akdeniz University. Procedia-Social and Behavioral Sciences, 2(2), 4820-4825. http://dx.doi.org/10.1016/j.sbspro.2010.03.777

Karacaoğlu, K., \& İnce, F. (2013). Pozitif örgütsel davranışın örgütsel sinizm üzerindeki etkileri: Kayseri ilindeki imalat sanayi işletmelerinde bir uygulama. Süleyman Demirel Üniversitesi İktisadi ve İdari Bilimler Fakültesi Dergisi, 18(1), 181-202.

Karadağ, E., Kılıçoğlu, G., \& Yılmaz, D. (2014). Organizational cynicism, school culture, and academic achievement: The study of structural equation modeling. Educational Sciences: Theory and Practice, 14(1), 102-113.

Kılıç, Ş. (2011). İlköğretim okulu öğretmenlerinin örgütsel sinizm ve örgütsel bağlllık düzeyleri arasındaki ilişsi (Keçiören ilçesi örneği) (Yayınlanmamış yüksek lisans tezi). Hacettepe Üniversitesi, Ankara, Türkiye.

Kızıltay, E. (2010). Yöneticilerin liderlik tarzlarına göre girişimcilik özelliklerinin incelenmesi: Tturizm sektöründe bir araştırma (Yayınlanmamış yüksek lisans tezi). Afyon Kocatepe Üniversitesi, Afyonkarahisar, Türkiye.

Korkmaz, M. (2007). The effects of leadership styles on organizational health. Educational Research Quarterly, $30(3), 22-54$.

Korkmaz, C. İ. (2011). Kişilik sinizmi ve algllanan üst yönetim desteğinin örgütsel sinizm üzerindeki etkisini incelemeye yönelik bir araştırma (Yayınlanmamış yüksek lisans tezi). Marmara Üniversitesi, İstanbul, Türkiye.

Kouzes, J., \& Posner, B. (2005). Leadership development is character development. Leadership Excellence, 22(2), 6-7.

Lee, C. H., \& Moon, J. (2011). Effects of officers' cynicism and their perception of managerial leadership on cop activities among South Korean police officers. Policing: An International Journal of Police Strategies and Management, 34(1), 31-48. http://dx.doi.org/10.1108/13639511111106597

Lobnikar, B., \& Pagon, M. (2004). The prevalence and the nature of police cynicism in Slovenia. Retrieved from https://www.ncjrs.gov/pdffiles1/nij/Mesko/ 207979.pdf

Lunenburg, F. C., \& Ornstein, A. C. (2012/2013). Eğitim Yönetimi (Çev. G. Arastaman). Ankara: Nobel Yayın Dağıtım. 
Mbera, P. G. A. (2015). Relationship between leadership styles used by head teachers of public secondary schools and students' academic performance. International Journal of Academic Research in Business and Social Sciences, 5(7), 226-239.

Mete, Y. A. (2013). Relationship between organizational cynicism and ethical leadership behaviour: A study at higher education. Procedia-Social and Behavioral Sciences, 89, 476-483. http://dx.doi.org/10.1016/j.sbspro.2013.08.880

Naus, A. J. M. (2007). Organizational cynicism: On the nature, antecedents, and consequences of employee cynicism toward the employing organization (Unpublished doctoral dissertation). University of Maastricht, Maastricht, Netherlands.

Nguyen, T. H. N. (2013). Examining multiple leadership styles and their influences on employee outcomes in the Auckland workplace: A mediation study (Unpublished master's thesis). Massey University, Wellington, New Zealand.

Ocak, S. (2014). Okul müdürü ve ögretmenlerin liderlik stillerinin bazı değişkenler açısından incelenmesi (Erzurum ili örneği) (Yayınlanmamış yüksek lisans tezi). İstanbul Üniversitesi, İstanbul, Türkiye.

Özdayı, N. (1998). Eğitim yöneticilerinin demokrasi ve hoşgörü tutumları ile liderlik özellikleri arasındaki ilişki. M. Ü. Atatürk Eğitim Fakültesi Ĕgitim Bilimleri Dergisi, 10(10), 221-235.

Özgan, H., Külekçi, E., \& Özkan, M. (2012). Analyzing of the relationships between organizational cynicism and organizational commitment of teaching staff. International Online Journal of Educational Sciences, 4(1), 196-205.

Özkan, Y. (2014). Okul yöneticilerinin liderlik stilleri ile okulların etkililik düzeyleri arasındaki ilişkinin incelenmesi (Yayınlanmamış yüksek lisans tezi). Mevlana Üniversitesi, Konya, Türkiye.

Polatcan, M. (2012). Okul yöneticilerinin liderlik davranışları ile öğretmenlerin örgütsel sinizm tutumları arasındaki ilişki (Yayınlanmamış yüksek lisans tezi). Sakarya Üniversitesi, Sakarya, Türkiye.

Robbins, S. P., \& Coulter, M. (2012). Management (11th ed.). New Jersey: Prentice Hall.

Sancak, Y. M. (2014). Etik liderlik örgütsel adalet ve örgütsel sinizm üzerine bir uygulama (Yayınlanmamış yüksek lisans tezi). Haliç Üniversitesi, İstanbul, Türkiye.

Şafaklı, O. V. (2005). KKTC'deki kamu bankalarında liderlik stilleri üzerine bir çalışma. Doğuş Üniversitesi Dergisi, 6(1), 132-143.

Tengilimoğlu, D. (2005). Kamu ve özel sektör örgütlerinde liderlik davranışı özelliklerinin belirlenmesine yönelik bir alan çalışması. Elektronik Sosyal Bilimler Dergisi, 4(14), 1-16.

Terzi, A. R., \& Kurt, T. (2005). İlköğretim okulu müdürlerinin yöneticilik davranışlarının öğretmenlerin örgütsel bağl1lı̆̆ına etkisi. Milli Ĕgitim Dergisi, 33(166), 98-113.

Terzi, A. R., \& Çelik, H. (2016). Liderlik stilleri ve algılanan örgütsel destek ilişkisi: Ilkokul ve lise öğretmenleri üzerinde bir araştırma. Ĕgitim ve Öğretim Araştırmaları Dergisi, 5(2), 87-98.

Tokgöz, N., \& Yılmaz, H. (2008). Örgütsel sinizm: Eskişehir ve Alanya'daki otel işletmelerinde bir uygulama. Anadolu Üniversitesi Sosyal Bilimler Dergisi, 8(2), 283-305.

Töyry, S., Kalimo, R., Äärimaa, M., Juntunen, J., Seuri, M., \& Räsänen, K. (2004). Children and work-related stress among physicians [Abstract]. Stress and Health, 20(4), 213-221. Retrieved from http://onlinelibrary.wiley. com/doi/10.1002/smi.1009/ abstract

Tura, M. (2012). İlköğretim okulu müdürlerinin liderlik stillerinin öğretmenlerin işdoyumuna etkisi/Karacabey ilçesi örneği (Yayınlanmamış yüksek lisans tezi). Balıkesir Üniversitesi, Balıkesir, Türkiye.

Tütüncü, Ö., \& Akgündüz, Y. (2012). Seyahat acentelerinde örgüt kültürü ve liderlik arasındaki ilişki: Kuşadası bölgesinde bir araştırma. Anatolia: Turizm Araştırmaları Dergisi, 23(1), 59-72.

Uluköy, M., Kılıç, R., \& Bozkaya, E. (2014). Hiyerarşik yapısı yüksek olan kurumlarda liderlik yaklaşımlarının çalışanların motivasyonu üzerine etkisi. Süleyman Demirel University Journal of Faculty of Economics and Administrative Sciences, 19(1), 191-206.

Woods, P. A. (2004). Democratic leadership: Drawing distinctions with distributed leadership. International Journal of Leadership In Education, 7(1), 3-26. Retrieved from http://www.tandfonline.com/doi /pdf/10.1080/ 1360312032000154522 
Wu, C., Neubert, M. J., \& Yi, X. (2007). Transformational leadership, cohesion perceptions, and employee cynicism about organizational change: The mediating role of justice perceptions. The Journal of Applied Behavioral Science, 43(3), 327-351.

Yalçınkaya, A. (2014). Türkiye'de örgütsel sinizm: 2007-2012 yılları arasındaki çalışmalar üzerine bir değerlendirme. Endüstri İlişkileri ve İnsan Kaynakları Dergisi, 16(3), 106-130.

Yetim, S. A., \& Ceylan, Ö. Ö. (2011). Örgütsel sinizm ve örgütsel vatandaşlık davranışları arasındaki ilişkiyi belirlemeye ilişkin bir araştırma. E-Journal of New World Sciences Academy, 6(1), 682-696.

Yıldız, K., Akgün, N., \& Yıldız, S. (2013). İşe yabancılaşma ile örgütsel sinizm arasındaki ilişki. The Journal of Academic Social Science Studies, 6(6), 1253-1284.

Yılmaz, K. (2004). Okul müdürlerinin destekleyici liderlik davranışları ile okullardaki güven arasındaki ilişki konusunda ilköğretim okulu öğretmenlerinin görüşleri. İnönü Üniversitesi Eğitim Fakültesi Dergisi, 5(8), 117-131.

Yörük, S., \& Kocabaş, İ. (2001). Eğitimde demokratik liderlik ve iletişim. Fırat Üniversitesi Sosyal Bilimler Dergisi, 11(1), 225-234.

Yörük, D., \& Dündar, S. (2011). Türkiye'deki yerel yöneticilerin benimsedikleri liderlik tarzlarına göre boyun eğici davranışların incelenmesi. Atatürk Üniversitesi İktisadi ve İdari Bilimler Fakültesi Dergisi, 25(1), 93-106.

Yukl, G. (1989). Managerial leadership: A review of theory and research. Journal of Management, 15(2), 251-289.

\section{Copyrights}

Copyright for this article is retained by the author(s), with first publication rights granted to the journal.

This is an open-access article distributed under the terms and conditions of the Creative Commons Attribution license (http://creativecommons.org/licenses/by/3.0/). 